\title{
"Impact of technology on different leadership styles to support distanced working: A study of India's service sector with reference to Delhi / NCR area"
}

\author{
N.Suresh Kumar \\ Research Scholar, Ph.D in Management, Amity University Uttar Pradesh, NOIDA, India
}

\section{Dr.(Ms) Shikha Kapoor}

Professor \& Area Chairperson - HR \& OB, Program Director - Ph.D. Program, Amity International Business School, Amity University Campus, NOIDA, India

\begin{abstract}
Indian service sector has witnessed the growth of technology at unprecedented pace that has impacted the creation and development of remote working environment. This changing organizational environment and market demands require an alignment between technology and leadership. In this context the current study aims to find the impact of technology on different leadership styles to support distanced working, particularly, after the spread of the global pandemic. For this, 328 respondents working in service sector of Delhi \&NCR were surveyedthrough structured questionnaire. Findings of the study revealed that technology has an influence on different leadership styles in supporting distanced working by providing clear communication, skill management, participation, or guiding work behavior. Additionally, technology plays significant role of enabling distanced working through contribution of technology in supporting communication and mobility, determination of technology task-fit, or creating of sense of unity. Thus, using the practices like cloud based internal communication portal or the reward and recognition facility, the benefit of technology could be derivedandbusiness continuity.
\end{abstract}

Keywords: Technology, Distanced working, Leadership styles, Indian service sector.

Article Received: 18 October 2020, Revised: 3 November 2020, Accepted: 24 December 2020

\section{Introduction}

Technology and its ever evolving and user centric enabling mechanisms and approaches are responsible for shifting the planning and execution of leadership in the modern world. With the development of technology, the workforce needs and aspirations have changed. There has been stimulation of growth in several industries including the service sector(Sexena, 2015).Technological advancement in the service sector has contributed tothe adoption of distanced working style, i.e. working through electronic processing, expanded telework opportunities, and increase collaboration through virtual teams without physical presence at a specific location/office. The culmination of these factors necessitates the need for new strategies and skills that help leaders meet market demands(Connally and Morris, 2017). Without the alignment between technology and leadership, it would be difficult for the organizations to meet the constantly shifting current market demands. Also without properly developed leadership competencies, organizations may face a risk of shrinking market share or market decline(Deboiset al., 2016).

Technological advancement has laid the groundwork for Fourth Industrial Revolution specifically in the service sector in India (ILO, 2018). Currently, Indian service sector is wellpositioned in terms of prevalence of remote working environments with presence of qualified manpower, a low-cost advantage, and previous service delivery track records in sectors like IT(Ganeshan and Vethirajan, 2020). The estimated revenue directed by the remote working by end of 2020 was $\$ 133-315$ billion(Dwivedi and Gopalakrishnan, 2020). Malhotra, (2020) reported in a study that, in India, 1 in 2 employees prefers telecommuting. Despite the importance of remote working environment in India, there have been only a few researches to explore the impact of technology on different leadership styles to support distanced working. As, with the growing 
technological advancement and the promotion of remote working environment, Indian service sector have the opportunity of improving their service delivery along with supporting productive working from qualified workforce. Thus, this study would focus on exploring the impact of technology with respect to service industries in India.

\section{Aim of study}

The current study aims to assess the impact of technology on different leadership styles to support remote working in India's service sector with reference to Delhi \& NCR.

\section{Literature Review}

\subsection{Types of leadership in India's service sector}

Among the different types of leadership in the Indian service sector, Kumar, (2014)shed light on the presence of three different styles. These include authoritarian, participative, and laissezfaire styles of leadership. In authoritarian leadership style, leaders pay less focus on the creation of inclusiveness in the team. Inputs from the group are rarely taken and the leader has control over all decisions. As they do not permit discussions, decision-making is a faster process(Busse and Regenberg, 2018). On the other hand, participative approach to leadership is a people-oriented approach. These leaders encourage direct feedback from subordinates and use positive reinforcement for efficiently handling them. Decision-making involves each or majority of members of the team which leads to an inclusive approach to team handling (Naik, 2015). Third, the laissez-faire approach of leadership is passive. The leader following this approach is reluctant to influence subordinates and provides them freedom and autonomy in work. Leadership under laissez faire is based on noninterference(Rassa and Emeagwali, 2020).

In addition, Ekkirala, Madhubala and Goute, (2013) also identified the prevalence of transactional and transformational leadership. Under transactional leadership, focus on the role of organization, supervision, and group performance is emphasized. These leaders use punishment and reward to attain compliance from followers. These leaders accept the existing organizational goals and structure and negotiate with the team for the attainment of these goals. Transactional leaders are primarily passive and strive to maintain the status quo(Kabeyi, 2018). Also, Budhiraja and Malhotra, (2013) shed light on transformational leadership practices in the Indian service sector. The author highlighted that following the transformational style, leaders focus on motivating subordinates through enthusiasm and visionary capabilities. The leadership style was further found to invoke positive behavior among employees including organizational commitment and job satisfaction in the service sector. These translate into proper orientation of subordinates towards the accomplishment of organizations' long-term goals(Tonkin, 2013).

\subsection{Role of technology in different leadership styles}

The role of technology in organizations varies according to the prevailing leadership styles. Klempin and Karp, (2018)found that under an authoritative leadership style, technology changes and implementation do not impact the underlying processes or structures in the organization. This is because the authoritative approach focuses on the maintenance of clear commands and hierarchy, which prevents adaptive role for the subordinates. On the other hand, the role of technology in the participative leadership approach is to manage skilled teams more efficiently. The leader uses technology to induce greater participation and engagement among teammembers. The participative leadership style allows the usage of technology in modern organizations to attain a more fluid approach and align employees towards the accomplishment of organizational goals (Sinani, 2016).

Also, Gemeda and Lee, (2020) in a study highlighted that role of technology is not significant in supporting distanced working under the laissez-faire leadership style. The author found the leadership style is weakly positively correlated with innovative work behavior and work engagement. Even, leadership does not impact 
work engagement or task performance among subordinates. In addition, Gençer and Samur, (2016) highlighted that role of technology is strongly correlated to the contingent reward factor of the transactional leadership approach. With the use of technology these leaders have formal control and power over subordinates and can make them focus on short-term goals. Farouk Soliman, (2016) found that transactional leadership has a significant effect on technology transfer effectiveness that allows the introduction of new techniques to subordinates and generation of new knowledge. Finally, the role of technology in transformational leadership has been established in a study by Tomi Mano, Thoyib and Maskie(2014). The author found that transformational leadership style is related to leader's innovation and responsibility in decisionmaking. It supports the integration of information and communication technology in organizations through the development of shared vision, individualized support, building consensus, and intellectual stimulation(Gençer and Samur, 2016).

\subsection{Importance of technology for enabling remote working, especially in leadership}

Considering the technological evolution and progress, it has been identified as a significant factor in enabling remote working trends. Technology paves the path for flexibility, virtual teams, inducing new ways of communication, and mobility for the creation of a remote working environment. However, the leader has to play an adaptive role to make proper use of technologies. This includes its usage for creation and utilization in a good technology-task-fit manner for the employee. At the same time, the leaders have to make use of social and cultural intelligence through virtual management tools to handle the geographically dispersed teams (Sivunen, Nurmi and Koroma, 2016; Großer and Baumöl, 2017). Also, technology is important for leaders as it allows them to maintain transparent, frequent, and consistent communication. In a distributed workforce, it helps to maintain two-way dialogue between leaders and their team hence easing up the remote working and navigation (Alward and Phelps, 2019).

Further, technology enable leaders to facilitate team members in gaining more autonomy and allows their real-time involvement (Schwarzmüller et al., 2018). Also, technology is important to ensure that leaders create a positive organizational environment. This is achieved by fostering a strong sense of unity and collaboration among employees by the usage of new-age information and communication technologies (Roman et al., 2019). Further, the role of technology for leaders in a remote working environment is to ensure informed decisions at a faster pace. Technology facilitates enormous amounts of real-time data for meaningful interpretations of results (Harris and Mehrotra, 2014; Vidgen, Shaw and Grant, 2017). Additionally, technologies help in the management of disruptive changes that may occur in unforeseen conditions to support employees' mental wellbeing. Guiding productivity and engagement level of employees through frequent meetings and clear performance expectations, implementation of technology based practices regulate the working of employees towards effective functioning of organization(Cortellazzo, Bruni and Zampieri, 2019). 


\subsection{Conceptual Framework}

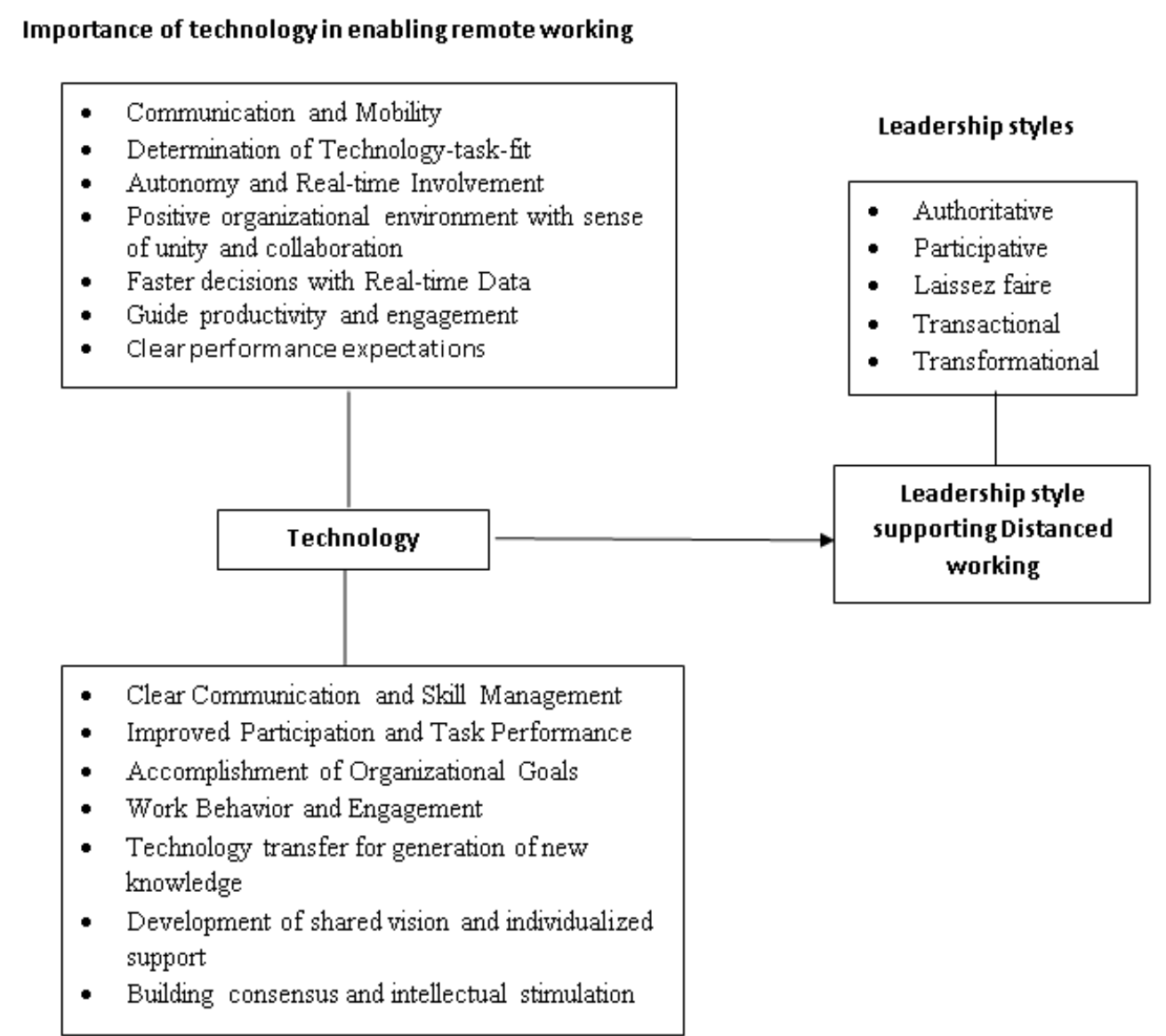

Figure 1: Conceptual Framework

The framework sheds light on the importance of technology for enabling remote working by stating its contributions i.e. enhancing communication, mobility, determination of technology-task-fit, autonomy, real-time involvement among the staff, positive organizational environment with a sense of unity and collaboration in making faster decisions with real-time data to guide productivity and engagement and provide the team with clear performance expectations. Further, focusing on the Technological impact on different leadership styles, Figure-1 shows that technology helps in clear communication and skill management, improved participation and task performance, accomplishment of organizational goals, create congruence in work behaviour and engagement, technology transfer for generation of new knowledge, development of shared vision, individualized support on need basis, building consensus and intellectual stimulation. As there are five major leadership styles, i.e., authoritative, participative, laissez-faire, transactional, and transformational, thus, the framework helps in building in the linkage between technology and different leadership styles in order to highlights the existing relationship between them.

\section{Research Methodology}

After identifying the critical elements of this research, the researcher conducted an empirical study consisting of the survey method to assess service sector employees' perception about how technology is affecting different leadership styles in their remote working environments. The target population consisted of employees working in the middle level operations of the firms, i.e., those in Senior Executives, Supervisors and Assistant Managers profiles. To this end, 5 different firms based in Delhi \& National Capital Region (NCR), namely, Faridabad, NOIDA and Gurgaon were approached which has a employee strength of over 
200 employees. These organizations were selected based on a set of similar characteristics which are as follows.

- Organizations with significant presence in the service sector, i.e. nation-wide scale and mid-sized firms.

- Organizations with IT/ ITES solutions as the primary service offering.

- Organizations not established later than 2010 and consisting of at least 200 employees.

Initially, 8 firms were approached out of which 5 agreed to participate in the study. An initial email was sent to the administration of each firm explaining the intent of this study and requesting their participation and assuring them that the responses of individual participating employees would be kept with utmost confidentiality. Based on their response, a sample of 100 employees from each firm were drawn based on the strata of working they belonged to, and they were contacted by their respective human resource department for participation in the survey. Therefore, purposive sampling method was applied to identify and select the respondents for the survey. Purposive sampling allowed the researcher to set the qualifying criteria as stated above. The sample size was determined using Cochran's formula i.e.

$$
n=\frac{z^{2} * p *(1-p)}{e^{2}}
$$

wherein,

n: sample size

z: confidence level z score value (1.96)

$\mathrm{p}$ : proportion of the population participating in the study

e: desired level of precision or margin of error

A structured, close-ended questionnaire was framed.

A Google Form was created and the link was shared with the representatives of the firms. The questionnaire consisted of questions pertaining to demographic, general background, and inferential section questions. This questionnaire was shared virtually with all identified employees $(n=500)$ across organizations and over the next two weeks, they were reminded to fill in their responses. At the end of the two weeks' period, only 328 employees responded by filling the questionnaires. Therefore, the final sample size of the study was 328 only. Their responses were extracted, coded and processed for hypothesis testing using SPSS software.

For fulfillment of the aim, the below stated hypothesis was tested.

$\mathrm{H}_{01}$ : Technology does not have an influence on different leadership styles in supporting distanced working.

$\mathrm{H}_{02}$ : Technology does not play a significant role in enabling distanced working

The demographic and background sections were analyzed using frequency analysis while hypotheses were tested using SPSS software. The data collected from the respondents is stored in password protected device to maintain privacy and even the entire analysis procedure focused on minimization of the biasness, thus, the results derived from this study are valid, reliable, and ethical.

\section{Data analysis}

For examining the impact of technology on different leadership styles, initially demographic profile of the respondents is examined. Herein the survey of 328 respondents shows that most of them belong to the age group of $30-40$ years that is $40.9 \%$, followed by those between $20-30$ years $(32 \%)$. Maximum of the respondents were male comprising $64 \%$ and female $36 \%$. Profession status shows that $81.1 \%$ of them are working full time. About $34.8 \%$ of them have experience of 510 years, followed by $31.1 \%$ employees with experience of 0 - 5 years, $21 \%$ with $10-15$ years, and $13 \%$ with more than 15 years of experience. Based on their monthly income, maximum employees earn Rs. 60000 - Rs. 80000, about $28 \%$ monthly income is in range of Rs. 40000 Rs. $60000,17.1 \%$ with Rs. $20000-40000,14.9 \%$ have income below Rs. 20000, and 9.1\% monthly income is more than Rs. 80000. 


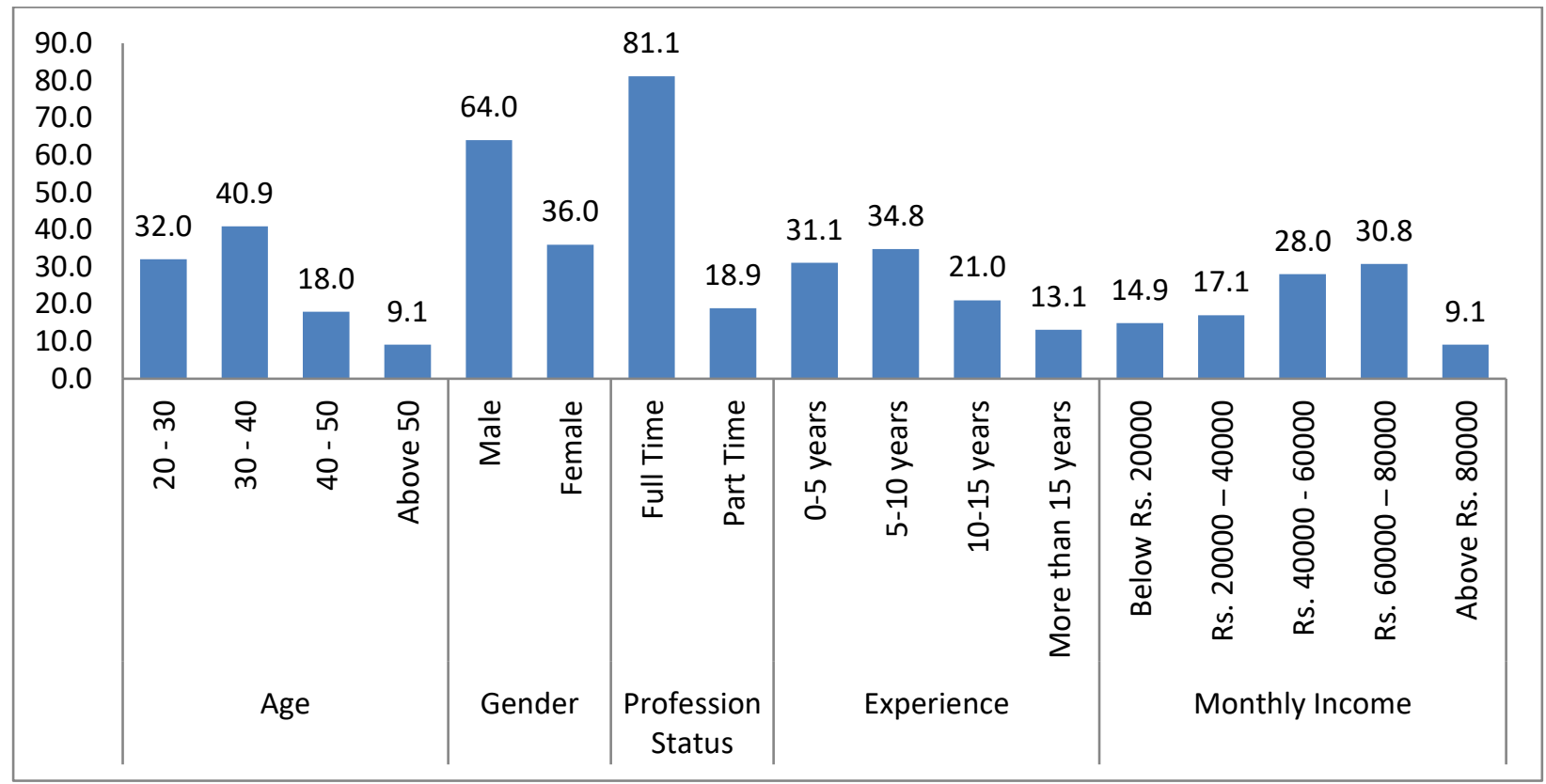

Figure 2: Demographic analysis

Further, background analysis shed light on knowledge among the respondents about the subject matter. Figure-2 herein reveals that respondents (96\%) are aware of the leadership styles being practiced by distanced leaders in their organization. Most of the respondents indicated that they were working under transformational leadership (51.2\%), 22\% of employees identified that their organization follow transactional style and $18.9 \%$ of them have participative style. Regarding the relationship between technology and leadership styles, $86.9 \%$ of the respondents agreed that technology impacts leadership styles. Further, it was found that $93 \%$ of respondents identified the role of technology in supporting distanced working. Lastly, the analysis revealed that enabling remote working environment helps in providing individualized support (22.3\%), intellectual stimulation (18.9\%), enhanced communication (18\%), shared vision (15.9\%), motivation(14.9\%), and enables building consensus $(10.1 \%)$.

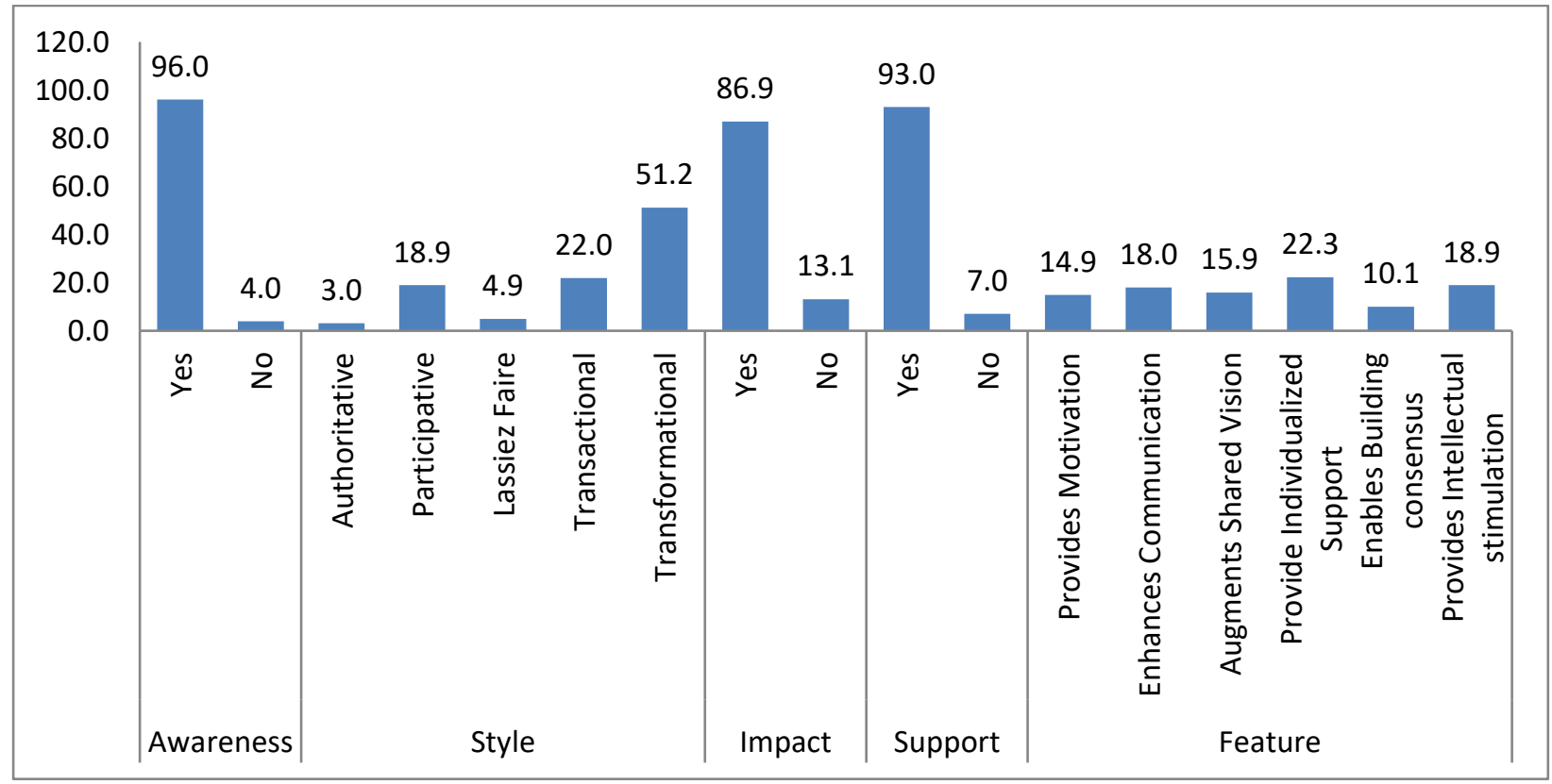

Figure 3: Background Analysis

Having the identification of the demographical characteristics and knowledge level of respondents, the linkage between technology and different leadership styles supporting distanced workingneed to be built. However, before this, the coding for the considered statements is done to 
reduce complexities. Below shown are the statements with their codes.

\begin{tabular}{|l|l|}
\hline Statement & Code \\
\hline $\begin{array}{l}\text { Technology influences different leadership styles in supporting distanced } \\
\text { working }\end{array}$ & S \\
\hline Enables clear communication and skill management & S1 \\
\hline Improves participation and task performance & S2 \\
\hline Develops shared vision and individualized support & S3 \\
\hline Helps in the accomplishment of organizational goals & S4 \\
\hline Promotes work behavior and engagement & S5 \\
\hline Augments technology transfer for the generation of new knowledge & S6 \\
\hline Builds consensus and intellectual stimulation & S7 \\
\hline Technology supports distance working & D \\
\hline Helps in communication and mobility & D1 \\
\hline Helps in the determination of technology-task-fit & D2 \\
\hline Contributes to autonomy and real-time involvement & D3 \\
\hline $\begin{array}{l}\text { Develops a positive organizational environment with sense of unity and } \\
\text { collaboration }\end{array}$ & D4 \\
\hline Enables faster decision making with real-time data & D5 \\
\hline Guides productivity and engagement & D6 \\
\hline Sets clear performance expectations & D7 \\
\hline
\end{tabular}

\section{Table 1: Coding for statements}

For the above statements the inferential analysis based on hypothesis testing is conducted as below:

\subsection{Influence of technology on different}

leadership styles in supporting

distanced working.

With the statement of coding in Table-1, the correlation analysis is undertaken done to

\begin{tabular}{|l|c|c|c|c|c|c|c|}
\hline \multicolumn{1}{|c|}{ S } & S1 & S2 & S3 & S4 & S5 & S6 & S7 \\
\hline $\begin{array}{l}\text { Pearson } \\
\text { Correlation }\end{array}$ & 0.557 & 0.588 & 0.467 & 0.610 & 0.532 & 0.463 & 0.496 \\
\hline $\begin{array}{l}\text { Sig. (2- } \\
\text { tailed) }\end{array}$ & 0.000 & 0.000 & 0.000 & 0.000 & 0.000 & 0.000 & 0.000 \\
\hline
\end{tabular}

Table 2:Correlation analysis for technology impact on leadership style supporting distance working Table 2 shows that significance value for all statement is less than 0.05 and Pearson correlation value is greater than 0.5 for $\mathrm{S} 1$ (0.557), S2 (0.588), S4 (0.610), andS5 (0.532). Thus, there is a possibility of having a significant influence of technology on different leadership styles supporting distance working. Further, for assessing the relationship, below stated hypothesis would be tested i.e. determine the linkage between technology and different leadership styles in supporting distanced working.
$\mathrm{H}_{01}$ : Technology does not have an influence on different leadership styles in supporting distanced working.

$\mathrm{H}_{\mathrm{A} 1}$ : Technology does have an influence on different leadership styles in supporting distanced working

Herein, regression analysis results are presented in the table below. 


\begin{tabular}{|l|r|r|r|r|r|l|}
\hline \multicolumn{1}{|c|}{ S } & Coefficients & T & $\begin{array}{c}\text { P } \\
\text { Value }\end{array}$ & $\mathbf{R}^{\mathbf{2}}$ & $\begin{array}{c}\text { Adjusted } \\
\mathbf{R}^{\mathbf{2}}\end{array}$ & F-ratio \\
\hline Constant & 0.431 & 2.847 & 0.005 & 0.560 & 0.555 & 102.948 \\
\hline S1 & 0.196 & 5.349 & 0.000 & & & \\
\hline S2 & 0.235 & 5.781 & 0.000 & & & \\
\hline S4 & 0.304 & 7.016 & 0.000 & & & \\
\hline S5 & 0.140 & 3.405 & 0.001 & & & \\
\hline
\end{tabular}

Table 3: Regression analysis for technology impact on leadership style supporting distance working The regression analysis reveals the $\mathrm{R}^{2}$ value of 0.560 and adjusted $\mathrm{R}^{2}$ value of 0.555 . This reveals that about $55.5 \%$ ofvariation in leadership styles is supporting distance working represented by technology. F-ratio is greater than 1 (102.948 > 1), hence precision of the model is derived by inclusion of respective independent statements. Pvalue for variables $\mathrm{S} 1, \mathrm{~S} 2, \mathrm{~S} 4$, and $\mathrm{S} 5$ are less than 0.05 , thus, the null hypothesis of technology having no influence on different leadership styles in supporting distanced working is rejected. Coefficient values for the variables depict that with $1 \%$ increase in usage of technology leads to rise in clear communication and skill management

(S1), participation and task performance (S2), accomplishment of organizational goals (S4), and work behavior and engagement (S5) by $0.196 \%$, $0.235 \%, 0.304 \%$, and $0.140 \%$ respectively. Thus, more usage of technology tends to positively influence the role of different leadership style in supporting distanced working.

\subsection{Role of technology in enabling distanced working}

Based on statements described in Table 2, the linkage between the technology and the distanced working environment is studied using correlation analysis. Herein, results of the is presented in below table.

\begin{tabular}{|c|c|c|c|c|c|c|c|}
\hline D & D1 & D2 & D3 & D4 & D5 & D6 & D7 \\
\hline $\begin{array}{c}\text { Pearson } \\
\text { Correlation }\end{array}$ & 0.537 & 0.551 & 0.508 & 0.523 & 0.399 & 0.510 & 0.601 \\
\hline Sig. (2-tailed) & 0.000 & 0.000 & 0.000 & 0.000 & 0.000 & 0.000 & 0.000 \\
\hline
\end{tabular}

\section{Table 4: Correlation analysis for role of technology and distanced working}

Based on the significance value of 0.00 which is less than 0.05 and Karl Pearson's correlation values for variables D1 (0.537), D2 (0.551), D3 (0.508),D4 (0.523), D6 (0.510), and D7 (0.601) > 0.5 , there is possibility of having relationship between the technology and distanced working environment. The impact assessment for these variables could be done by having the statistical test of below stated hypothesis at 5\% level of significance.

$\mathrm{H}_{02}$ : Technology does not play a significant role in enabling distanced working

$\mathrm{H}_{\mathrm{A} 2}$ : Technology does play a significant role in enabling distanced working

Thus, for relationship building, regression analysis is performed, results for which is shown in below table.

\begin{tabular}{|l|r|r|r|r|r|r|}
\hline \multicolumn{1}{|c|}{ D } & Coefficient & $\begin{array}{c}\text { T- } \\
\text { statistic }\end{array}$ & $\begin{array}{c}\text { p- } \\
\text { value }\end{array}$ & $\mathbf{R}^{\mathbf{2}}$ & $\begin{array}{c}\text { Adjusted } \\
\mathbf{R}^{\mathbf{2}}\end{array}$ & F ratio \\
\hline Constant & 0.184 & 0.975 & 0.330 & 0.522 & 0.513 & 58.438 \\
\hline D1 & 0.262 & 5.142 & 0.000 & & & \\
\hline D2 & 0.155 & 3.093 & 0.002 & & & \\
\hline D3 & 0.070 & 1.342 & 0.189 & & & \\
\hline D4 & 0.152 & 3.314 & 0.001 & & & \\
\hline D6 & 0.094 & 1.594 & 0.112 & & & \\
\hline
\end{tabular}




\begin{tabular}{|l|l|l|l|}
\hline D7 & 0.226 & 4.201 & 0.000 \\
\hline
\end{tabular}

Table 5: Regression analysis for role of technology on distanced working

Table 5 depicts the value of $\mathrm{R}^{2}$ is 0.522 and adjusted $\mathrm{R}^{2}$ value of 0.513 This shows that about $51.3 \%$ variation in distance working is caused by technology. F-ratio value is 58.438, which is greater than 1 showing more precision derivation by including respective independent statements. P-value of D1 (0.000), D2 (0.002), D4 (0.001), and D7 $(0.000)<0.05$, thus, the null hypothesis of having no significant role of technology in enabling distanced working is rejected. Coefficient value represents that with $1 \%$ increase in the role of technology, there is better communication and mobility (D1), determination of technology task-fit (D2), sense of unity and collaboration (D4), and clear performance expectation (D7) increases by $0.262 \%, 0.155 \%$, $0.152 \%$, and $0.226 \%$ respectively. Thus, usage of technology tends to support distanced working.

\section{Conclusion}

The Indian service sector faces a critical challenge today: to improve its service delivery process with minimal cost to the company. This, in addition to the sudden large-scale shift to remote working environment in view of the new normal has prompted companies to bring the spotlight on efficient management of their primary resource, i.e., manpower. The prevalence of remote working environments in the service sector in India is augmented by the presence of qualified manpower, a low-cost advantage, and previous track records. In their quest for perfecting the leadership style best suited for their environment, companies are turning to technology. Technology is playing a critical role in every function of a business today. It has assisted companies in improving leadership in order to make them better suited for remote working environments.

To complement distance working, five major forms of leadership are present in the Indian service sector i.e. authoritative, participative, laissez-faire, transactional, and transformational. It was found in this study that technology enables remote working trends by paving path for flexibility, communication, virtual teams, and mobility along with allowing the usage of social and cultural intelligence through virtual management tools.Thus, this study focused on determining the impact of technology on different leadership styles in the remote working environment by surveying 328 respondents. Maximum of them were from age group 20-40 years and employed full time in distance working. Transformational style is most prevalent in service sector organizations in India.The analysis revealed that technology has an influence on different leadership styles in supporting distanced working by providing clear communication, skill management, participation, task performance, accomplishment of goals, guiding work behavior, and engagement. Also, through contribution of technology in supporting communication and mobility, determination of technology task-fit, sense of unity and collaboration, and clear performance expectation; there is significant role of technology in enabling distanced working. Based on these findings, the below stated strategies are recommended to be implemented by organizations.

- Communication mediums like internal portals or blogs should be developed for facilitating flexibility and clearance in communication.

- Internal communication standards and documentation should be maintained for minimizing misinterpretation.

- Employees should be motivated in form of rewards and recognition for the team such as monetary rewards and certificates of appreciation for promoting work behaviour, engagement, and intellectual stimulation in distanced working.

Future studies centered on remote working environments and leadership can expand on the findings of this study by selecting a larger sample size from a diverse group of service sector firms across the country, identifying specific elements of leadership and technology that affect the company's productivity. 


\section{References}

[1] Alward, E. and Phelps, Y. (2019) 'Impactful leadership traits of virtual leaders in higher education', Online Learning, 23(3), pp. 72-93. doi: 10.24059/olj.v23i3.2113.

[2] Budhiraja, S. and Malhotra, M. (2013) 'Leadership Style \& Organizational Effectiveness in Indian IT \& Banking Industry', Indian Journal of Industrial Relations, 49(2), pp. 270-285.

[3] Busse, R. and Regenberg, S. (2018) 'Revisiting the "Authoritarian Versus Participative" Leadership Style Legacy: A New Model of the Impact of Leadership Inclusiveness on Employee Engagement', Journal of Leadership and Organizational Studies, 26(1), pp. 510-525. doi: 10.1177/1548051818810135.

[4] Connally, P. N. and Morris, L. R. (2017) 'The Impact of Emerging Technology on Leadership Development', in Kidd, T. and Morris, R. L. J. (eds) Handbook of research on instructional systems and educational technology. Hershey PA, USA: IGI Global, pp. 400-408. doi: 10.4018/978-1-5225-2399-4.ch034.

[5] Cortellazzo, L., Bruni, E. and Zampieri, R. (2019) 'The role of leadership in a digitalized world: A review', Frontiers in Psychology, 10(AUG). doi: 10.3389/fpsyg.2019.01938.

[6] Debois, P. et al. (2016) The DevOps Handbook: How to Create World-Class Agility, Reliability, and Security in Technology Organizations. Portland, US: IT Revolution Press.

[7] Dwivedi, K. and Gopalakrishnan, B. N. (2020) 'COVID-19 | Resetting The Offshore Industry To Help India's Job Market', Money Control, May.

[8] Ekkirala, V., Madhubala, M. and Goute, D. A. K. (2013) 'Transformational and Transactional Leadership in the Indian Context Abstract':, International Journal
Of Innovative Research \& Development, 2(12), pp. 237-243.

[9] Farouk Soliman, A. (2016) 'Investigating the Leadership Style Effect on the Technology Transfer Effectiveness: A Proposed New Model (An Applied Study on the Dairy Manufacturing Sector in Egypt)', International Journal of Business and Management, 11(10), pp. 141-161. doi: 10.5539/ijbm.v11n10p141.

[10] Ganeshan, M. K. and Vethirajan, C. (2020) 'Skill Development Initiatives And Employment Opportunity In India', An International Peer Reviewed Refereed Journal, 1(3), pp. 21-28. doi: 08.202062386357.

[11] Gemeda, H. K. and Lee, J. (2020) 'Leadership styles, work engagement and outcomes among information and communications technology professionals: A cross-national study', Heliyon, 6(4), p. e03699. doi:

10.1016/j.heliyon.2020.e03699.

[12] Gençer, M. S. and Samur, Y. (2016) 'Leadership Styles and Technology: Leadership Competency Level of Educational Leaders', Procedia - Social and Behavioral Sciences, 229, pp. 226233. doi: 10.1016/j.sbspro.2016.07.132.

[13] Großer, B. and Baumöl, U. (2017) 'Virtual teamwork in the context of technological and cultural transformation', International Journal of Information Systems and Project Management, 5(4), pp. 21-35. doi: 10.12821/ijispm050402.

[14] Harris, J. G. and Mehrotra, V. (2014) 'Getting value from your data scientists', MIT Sloan Management Review.

[15] ILO (2018) Emerging technologies and the future of work in India. doi: ISSN: 22274391; 2227-4405.

[16] Kabeyi, M. J. B. (2018) 'Transformational Vs Transactional Leadership with Examples', The International Journal Of Business \& Management, 6(5), pp. 191193. 
[17] Klempin, S. and Karp, M. M. (2018) 'Leadership for Transformative Change: Lessons From Technology-Mediated Reform in Broad-Access Colleges', The Journal of Higher Education, 89(1), pp. 81-105. doi: 10.1080/00221546.2017.1341754.

[18] Kumar, P. (2014) 'Leadership styles in insurance sector: a critical appraisal of life insurance corporation of India', Asian Journal Of Management Research, 4(3), pp. 441-455.

[19] Malhotra, H. S. (2020) 'GIG Economy Aligning Consumer Preferences: The Way Forward', in National Conference Gig Economy Aligning Consumer Preferences: The Way Forward. New Delhi: The Associated Chambers of Commerce and Industry of India.

[20] Naik, S. D. (2015) 'Leadership Styles in India- An empirical Study of Indian Entrepreneurs/Leaders', Ushus - Journal of Business Management, 14(2), pp. 37-52. doi: 10.12725/ujbm.31.3.

[21] Rassa, H. A. and Emeagwali, L. (2020) 'Laissez fair leadership role in organizational innovation: The mediating effect of organization structure', Management Science Letters, 10(7), pp. 1457-1462. doi: 10.5267/j.msl.2019.12.022.

[22] Roman, A. V. et al. (2019) 'Defining Eleadership as Competence in ICTMediated Communications: An Exploratory Assessment', Public Administration Review. doi: 10.1111/puar.12980.

[23] Schwarzmüller, T. et al. (2018) 'How does the digital transformation affect organizations? Key themes of change in work design and leadership', Management Revue, 29(2), pp. 114-138. doi: 10.5771/0935-9915-2018-2-114.

[24] Sexena, D. K. (2015) 'Position of Information Technology in Service Sector of Indian Economy', Journal of Commerce and Trade, 10(2), pp. 98-102.

[25] Sinani, F. (2016) ScholarWorks The Effects of Participative Leadership Practices on Job Satisfaction for Highly Skilled Virtual Teams.

[26] Sivunen, A., Nurmi, N. and Koroma, J. (2016) 'When a one-hour time difference is too much: Temporal boundaries in global virtual work', in Proceedings of the Annual Hawaii International Conference on System Sciences. IEEE Computer Society, pp. 511-520. doi: 10.1109/HICSS.2016.70.

[27] Tomi Mano, B., Thoyib, A. and Maskie, G. (2014) Effect of Transformational Leadership Style, Information Technology, Organization Culture and Leader Innovation on Leader Performance (Study in Jayapura City Government), International Journal of Business and Management Invention ISSN. Online.

[28] Tonkin, T. (2013) 'Authentic versus Transformational Leadership: Assessing thier Effectiveness on Organizational Citizenship Behavior of Followers', International Journal of Business and Public Administration, 10(1), pp. 40-60.

[29] Vidgen, R., Shaw, S. and Grant, D. B. (2017) 'Management challenges in creating value from business analytics', European Journal of Operational Research, 261, pp. 626-639. doi: 10.1016/j.ejor.2017.02.023.

[30] Shah, Mehul K., Chetan B. Bhatt, and Jaimin B. Dave. "NIR spectroscopy: Technology ready for food industries applications." International Journal of Applied and Natural Sciences (IJANS) 5.1 (2016) 129-138.

[31] KIM, KAYK. "AN EFFECTIVE INVENTORY TRACKING SYSTEM WITH THE USE OF IT TECHNOLOGY IN RETAIL INDUSTRY." IMPACT: International Journal of Research in 
Business Management (IMPACT: IJRBM)

4.4 (2016) 1-8

[32] CHEN, CYJ. "SOCIAL ACTIVISM IN SOCIAL SCIENCE EDUCATION: A SCIENCE, TECHNOLOGY, AND EFFECTS OF SOCIAL SCIENCES IN MEDIA SOCIETY." IMPACT: International Journal of Research in Humanities, Arts and Literature (IMPACT: IJRHAL) 4.5 (2016) 5-12

[33] BELKUR, ABDLBAST AMAR, and REENA MEHTA. "REFRAIN OF ORGANIZATIONAL CULTURE IN ENHANCING PARTICIPATION IN DECISION-MAKING TO CONFRONT WITH CHALLENGES FIELD STUDY OF LIBYAN INFORMATION AND COMMUNICATIONS TECHNOLOGY COMPANIES." IMPACT: International
Journal of Research in Business Management (IMPACT: IJRBM) 4.5 (2016) 45-64

[34] KAMALA, MERLIN, et al. "ANALYSIS OF TECHNOLOGY GAPS AND RELATIVE IMPORTANCE OF JASMINE BUDWORM, HENDECASIS DUPLIFASCIALIS HAMPSON IN TAMIL NADU." International Journal of Agricultural Science and Research (IJASR) 7.2 (2017) 319-324

[35] Si, Ferianto S., and Mahardhika Berliandaldo Se. "Technology Transfer Management in Pharmaceutical Industry Through Freedom to Operate (Fto) Utilization." International Journal of Business Management \& Research (IJBMR) 7.2 (2017): 59-66.

\section{Section A: Demographic Profile}

\section{Survey Questionnaire}

1. What is your age?
a) $20-30$
b) $30-40$
c) $40-50$
d) Above 50

2. What is your Gender?

a) Male

b) Female

3. What is your profession status?
a) Full Time
b) Part Time

4. How many years of experience with organization?
a) 0-5 years
b) 5-10 years
c) $10-15$ years
d) More than 15 years

5. What is your monthly income?
a) Below Rs. 20000
b) Rs. $20000-40000$
c) Rs. $40000-60000$
d) Rs. $60000-80000$
e) Above Rs. 80000

\section{Section B: General background}

6. Are you aware of the leadership style followed in your organization? 

a) Yes
b) No

7. What type of leadership is followed in your organization?
a) Authoritative
b) Participative
c) Lassiez-Faire
d) Transactional
e) Transformational

8. According to you is there any impact of technology in leadership style?
a) Yes
b) No

9. According to you does technology support distance working?
a) Yes
b) No

10. What according to you is the relevance of enabling remote working environment in your organization?
a) Provides Motivation
b) Enhances Communication
c) Augments Shared Vision
d) Provide Individualized Support
e) Enables Building consensus
f) Provides Intellectual stimulation

\section{Section C: Inferential Analysis}

Rate the following on the basis of your perception on the impact of technology on leadership styles in remote working environment on a scale of 1-5 where 1 - strongly Disagree, 2 - Disagree, 3 - Neutral, 4 Agree, and 5 - Strongly Agree

11. Do you think that technology impact different leadership styles to support distanced working?
a) Strongly disagree
b) Disagree
c) Moderate
d) Agree
e) Strongly agree

\begin{tabular}{|c|c|c|c|c|c|c|}
\hline No. & Statement & 1 & 2 & 3 & 4 & 5 \\
\hline 1 & $\begin{array}{l}\text { Enables Clear Communication and Skill } \\
\text { Management }\end{array}$ & & & & & \\
\hline 2 & Improves Participation and Task Performance & & & & & \\
\hline 3 & Develops shared vision and individualized support & & & & & \\
\hline 4 & Helps in Accomplishment of Organizational Goals & & & & & \\
\hline 5 & Promotes Work Behaviour and Engagement & & & & & \\
\hline 6 & $\begin{array}{l}\text { Augments Technology transfer for generation of new } \\
\text { knowledge }\end{array}$ & & & & & \\
\hline 7 & Builds consensus and intellectual stimulation & & & & & \\
\hline
\end{tabular}

12. Do you think that technology supports distanced working?

f) Strongly disagree

g) Disagree

h) Moderate

i) Agree 
j) Strongly agree

\begin{tabular}{|r|l|l|l|l|l|l|}
\hline No. & Statement & 1 & 2 & 3 & 4 & 5 \\
\hline 1 & Helps in Communication and Mobility & & & & & \\
\hline 2 & Helps in Determination of Technology-task-fit & & & & & \\
\hline 3 & $\begin{array}{l}\text { Contributes to Autonomy and Real-time } \\
\text { Involvement }\end{array}$ & & & & & \\
\hline 4 & $\begin{array}{l}\text { Develops Positive organizational environment } \\
\text { With sense of unity and collaboration }\end{array}$ & & & & \\
\hline 5 & $\begin{array}{l}\text { Enables Faster decision making with Real-time } \\
\text { Data }\end{array}$ & & & & \\
\hline 6 & Guides productivity and engagement & & & & & \\
\hline 7 & Sets Clear performance expectations & & & & & \\
\hline
\end{tabular}

